\title{
De implementatie van 'Samen beslissen' in het ziekenhuis en de werkdruk van zorgprofessionals
}

\author{
Roel Schouteten \& Lotte Jansen *
}

Deze studie onderzoekt het effect van de interventie 'Samen beslissen' op de werkdruk voor zorgprofessionals in een ziekenhuis. 'Samen beslissen' is een vorm van gezamenlijke besluitvorming waarin patiënten actief worden betrokken. Internationaal empirisch onderzoek laat zien dat dergelijke interventies een positief effect hebben op patiëntgerelateerde uitkomsten, maar er is nog nauwelijks onderzoek gepubliceerd naar de effecten hiervan voor zorgprofessionals.

Met het Job Demands-Resources model als theoretische lens hebben we bestudeerd welke mechanismen een rol spelen als 'Samen beslissen' wordt toegepast bij patiënten die werden gediagnosticeerd met prostaatkanker. We hebben kwalitatieve data verzameld rondom de besluitvormingsprocessen bij tien patiënten waarbij twee zorgprofessionals betrokken zijn.

Naast een bevestiging van de positieve effecten voor patiënten laten de resultaten zien dat ook de zorgprofessionals de nieuwe manier van besluitvorming als positief ervaren. In termen van werkdruk zien we een goede balans tussen werkeisen en energiebronnen. Deze positieve effecten zijn te relateren aan de zorgvuldigheid waarmee een dergelijke andere manier van werken wordt ingevuld en geïmplementeerd. Dat betekent dat een zorgvuldige implementatie van een nieuwe manier van werken kan bijdragen aan het in de hand houden van werkdruk en zelfs kan bijdragen aan het welzijn van medewerkers in een sector die kampt met hoge werkdruk.

\section{$1 \quad$ Inleiding}

De zorgsector kampt met hoge werkdruk (CBS, 2016). Uit gegevens van de Nationale Enquête Arbeidsomstandigheden concludeert het CBS (2016) dat in de zorg werknemers hard moeten werken (veel werk doen en snel moeten werken), dat het werk emotioneel zwaar is, en dat dat gepaard gaat met relatief beperkte autonomie. Oorzaken van deze hoge werkdruk lopen uiteen van personeelstekorten als gevolg van vergrijzing, en toegenomen administratieve last als gevolg van toenemende nadruk op verantwoording van de kwaliteit van zorg, tot snelle (technologische) ontwikkelingen die veranderingen in de aard van het werk met zich meebrengen. In deze studie gaan we dieper in op de werkdrukeffecten van een verandering in de manier van werken die is gericht op het verbeteren van de kwaliteit van zorg aan patiënten in een ziekenhuis. Dit onderzoek gaat over de imple-

* Roel Schouteten is verbonden aan het Institute for Management Research van de Radboud Universiteit. Correspondentieadres: Roel Schouteten, Postbus 9108, 6500 HK Nijmegen. E-mail: r.schouteten@fm.ru.nl. Lotte Jansen is als projectmanager werkzaam bij CSU. Ten tijde van het onderzoek was zij masterstudent SHRM aan de Radboud Universiteit. 
mentatie van 'Samen beslissen' in het behandelproces van patiënten die met prostaatkanker zijn gediagnosticeerd.

'Samen beslissen' is een manier van besluitvorming over gezondheidsbehandelingen waarin patiënten actief in de besluitvorming worden betrokken. Een behandelend arts en patiënt delen informatie en kennis over een aandoening en de patiënt wordt gestimuleerd om verschillende behandelopties te overwegen en een voorkeur te ontwikkelen (Elwyn et al., 2010). Op basis daarvan besluiten behandelaar en patiënt gezamenlijk welke behandeling er wordt gevolgd. Deze manier van besluitvorming wordt veelal ingevoerd om het zorgproces voor patiënten te verbeteren en er wordt nadrukkelijk gepleit om patiënten actief in de besluitvorming over hun behandeling te betrekken (Brock \& Wartman, 1990; Coulter, 1997; Deber, 1994; Emanuel \& Emanuel, 1992; Gray, Doan, \& Church, 1990; Levine, Gafni, \& Markham, 1992). Uit een veelheid aan empirische studies is gebleken dat gezamenlijke besluitvorming een positief effect heeft op patiëntgerelateerde uitkomsten, zoals gezondheid, kennis en tevredenheid van patiënten (Benbassat, Pilpel, \& Tidhar, 1998; Butcher, 2013; Griffin et al., 2004; Guadagnoli \& Ward, 1998; Stacey et al., 2017; Stiggelbout, Pieterse, \& De Haes, 2015).

Er is echter nog nauwelijks onderzoek gepubliceerd naar de effecten van gezamenlijke besluitvorming voor zorgprofessionals, zoals artsen en (verpleegkundig) specialisten. Op basis van een onderzoek onder Britse zorgmedewerkers (National Health Service, 2011) valt te verwachten dat een hogere patiënttevredenheid (als gevolg van gezamenlijke besluitvorming) gepaard gaat met een hogere tevredenheid onder zorgprofessionals. Maar gezamenlijke besluitvorming is ook van invloed op de manier van werken van zorgprofessionals. De manier van werken in termen van de balans tussen werkeisen en energiebronnen (Demerouti Bakker, Nachreiner, \& Schaufeli, 2001; Karasek, 1978) is van invloed op de werkdruk. Bij gezamenlijke besluitvorming geven zorgprofessionals een deel van de besluitvorming uit handen. Dat vergt een andere manier van werken, plannen, voorbereiden en afstemmen van werkzaamheden en verantwoordelijkheden. Het brengt ook andere interacties met patiënten en collega's met zich mee. Daarbij is het ook mogelijk dat niet alle patiënten op dezelfde manier met de eigen verantwoordelijkheid (kunnen) omgaan. Dat vereist meer flexibiliteit van de behandelaar. Maar er is dus nog geen empirisch onderzoek naar dergelijke effecten.

Om meer inzicht te geven in de mogelijke werkdrukeffecten van gezamenlijke besluitvorming hebben we een exploratief onderzoek gedaan rondom de interventie van 'Samen beslissen' in een Nederlands ziekenhuis. Het doel hiervan is om de mechanismen bloot te leggen die verklaren of en hoe een interventie gericht op gezamenlijke besluitvorming bijdraagt aan de werkdruk van zorgprofessionals in ziekenhuizen. Hiermee willen we ook bijdragen aan de door Légaré et al. (2018) geconstateerde onduidelijkheid over welke interventies op welke manier bijdragen aan het succesvol implementeren van gezamenlijke besluitvorming in ziekenhuizen. Volgens Légaré et al. (2018) zijn er vele verschillende manieren om gezamenlijke besluitvorming te implementeren, maar is er nog weinig eenduidigheid in welke het best werken om gezamenlijke besluitvorming te implementeren. Met ons onderzoek naar de mogelijke werkdrukeffecten kunnen we mechanismen blootleggen die bijdragen aan het succesvol implementeren van gezamenlijke 
besluitvorming, want als het leidt tot meer werkdruk, zal de acceptatie door zorgprofessionals beperkt zijn.

In dit artikel gaan we eerst dieper in op gezamenlijke besluitvorming en wat daarvan de mogelijke effecten op werkdruk zijn. Daarvoor gebruiken we het Job Demands-Resources model (Demerouti et al., 2001) als theoretische lens. Daarna volgen de methodologie en de resultaten, waarna we afsluiten met een conclusie en discussie.

\section{Gezamenlijke besluitvorming}

In gezamenlijke besluitvorming in de gezondheidszorg kunnen verschillende fases worden onderscheiden (Elwyn et al., 2012; Stiggelbout et al., 2015). Eerst informeert de behandelaar (een arts of een andere zorgprofessional) de patiënt dat er verschillende opties mogelijk zijn bij de behandeling van een aandoening en dat de mening van de patiënt een belangrijke rol speelt bij de keuze van de behandeloptie. Doel van deze fase is om duidelijk te maken dat er keuzemogelijkheden zijn. In de tweede fase geeft de behandelaar meer details over de verschillende opties, inclusief de voor- en nadelen van elke optie. In de derde fase bespreken behandelaar en patiënt de voorkeuren van de patiënt. Daarbij ondersteunt de behandelaar de patiënt bij het onderbouwen van een voorkeur om te komen tot een keuze. In de laatste fase wordt de keuze voor een behandeling vastgesteld en worden afspraken voor de vervolgstappen gemaakt.

De mate waarin deze fasen expliciet worden doorlopen en in het behandelproces worden geïntegreerd, zijn bepalend voor de mate waarin de patiënt ervaart bij de besluitvorming betrokken te zijn. Dit draagt bij aan de positieve effecten die gezamenlijke besluitvorming kan opleveren. Als de voorkeuren van patiënten expliciet worden meegewogen, leidt dat tot meer tevredenheid over het zorgproces bij patiënten (Butcher, 2013; Conway \& Willcocks, 1997). Die tevredenheid wordt veroorzaakt door groter zelfvertrouwen van de patiënten als ze in de keuze worden betrokken (Ware, Davies-Avery, \& Stewart, 1978), meer en betere informatie en kennis bij de patiënten over de keuzemogelijkheden en voor- en nadelen daarvan (Elwyn et al., 2012; Stacey et al., 2017), een betere relatie tussen zorgprofessional en patiënt (Stiggelbout et al., 2015; Tucker \& Adams, 2001), en meer vertrouwen in een goede afloop (Edwards \& Elwyn, 1999; O'Connor et al., 1999). Daarnaast zijn er ook studies die aantonen dat gezamenlijke besluitvorming bijdraagt aan positieve gezondheidseffecten, zoals psychologisch welzijn, gewichtsafname, en minder angst- en depressie-klachten (Benbassat et al., 1998; Griffin et al., 2004; Guadagnoli \& Ward, 1998).

Ook zijn er voordelen voor ziekenhuizen en de zorgsector in het algemeen. Patiënten kiezen vaak minder intensieve en goedkopere behandelingen als ze zelf kunnen kiezen (Butcher, 2013). Ook wordt er minder vaak voor niet-noodzakelijke ingrepen ('elective surgery'; Stacey et al., 2017) gekozen en vermindert het aantal aanvragen voor 'second opinions' en vervolgafspraken (Stiggelbout et al., 2015). Dit zorgt voor lagere kosten voor gezondheidszorg. 
In het proces van gezamenlijke besluitvorming worden vaak ondersteunende hulpmiddelen gebruikt om de patiënten op een goede manier in het besluitvormingsproces te betrekken. Een voorbeeld hiervan zijn zogenaamde keuzehulpen. Keuzehulpen zijn samenvattende overzichten van de keuzemogelijkheden, vaak overzichtelijk op één vel papier naast elkaar om snel overzicht te krijgen. Vaak wordt dat aangevuld met veelgestelde vragen door patiënten, zoals 'wat zijn bekende bijverschijnselen van een behandeling?' of 'wanneer kan ik weer aan het werk?'. Deze keuzehulpen zijn ook bedoeld om bij gesprekken tussen zorgprofessionals en patiënten te gebruiken (Elwyn et al., 2013). Het gebruik hiervan draagt bij aan de informatie-uitwisseling tussen zorgprofessional en patiënt, en betrekt patiënten expliciet in het besluitvormingsproces.

\section{Gezamenlijke besluitvorming en werkdruk}

Er is weinig onderzoek naar het effect van de implementatie van gezamenlijke besluitvorming voor de manier van werken van zorgprofessionals en welke effecten dat voor hen heeft, bijvoorbeeld in termen van werkdruk. Een verandering in de manier van werken, zeker in een sector die wordt gekenmerkt door een hoge werkdruk, kan allerlei effecten hebben voor werkdruk. Literatuur over gezamenlijke besluitvorming in de gezondheidszorg geeft wel aan hoe een dergelijk proces er idealiter uit zou moeten zien (zie de fasen zoals beschreven in Elwyn et al., 2012; Stiggelbout et al., 2015). En er zijn ook studies naar de manieren van implementatie die bijdragen aan het gebruik van gezamenlijke besluitvorming in de gezondheidszorg (Légaré et al., 2018). Maar hoe dergelijke implementaties de manier van werken, en daarmee de werkdruk, beïnvloeden, is nog niet bestudeerd.

Werkdruk is een onbalans tussen wat het werk van de medewerker vraagt (werkeisen) en de mogelijkheden in het werk om daarmee om te gaan (regelmogelijkheden, energiebronnen). Daarmee is werkdruk een gevolg van de manier waarop het werk is georganiseerd. Volgens Christis (1999, p. 73) leidt werkdruk ertoe dat iemand niet of maar met moeite aan de kwantitatieve en kwalitatieve eisen van het werk kan voldoen. De balans tussen werkeisen en regelmogelijkheden is ontleend aan het Job Demands-Decision Latitude model van Karasek (1979) en is ook terug te vinden in het Job Demands-Resources model (Demerouti et al., 2001; Schaufeli \& Taris, 2013). Een onbalans tussen werkeisen (job demands) en energiebronnen (job resources) kan leiden tot gevoelens van burnout als de werkeisen groter zijn dan de energiebronnen (Demerouti et al., 2001), maar ook tot verveling (boreout; Werder \& Rothlin, 2007) als de regelmogelijkheden niet benut hoeven te worden om aan de werkeisen te voldoen.

Werkeisen zijn alle fysieke, sociale en organisatorische aspecten van het werk die een beroep doen op aanhoudende fysieke en mentale inspanning van medewerkers en daarom worden geassocieerd met fysiologische en psychologische kosten (vermoeidheid) (Demerouti et al., 2001, p. 501). Voorbeelden van werkeisen zijn werkhoeveelheid, moeilijkheid/complexiteit van het werk, emotionele belasting, regelproblemen die om oplossingen vragen, en onduidelijkheden over wat er moet worden gedaan en wat je daarbij van anderen kunt verwachten. Energiebronnen 
zijn alle fysieke, sociale en organisatorische aspecten van het werk die een van de volgende kenmerken hebben: (1) bijdragen aan het bereiken van de werkdoelen, (2) verminderen van de werkeisen voor wat betreft de fysiologische en psychologische kosten, of (3) persoonlijke groei of ontwikkeling stimuleren (Demerouti et al., 2001, p. 501). Voorbeelden van energiebronnen zijn autonomie, sociale steun van leiding en collega's, inspraak, feedback/informatievoorziening, en leer- en ontwikkelingsmogelijkheden.

Gezamenlijke besluitvorming brengt potentieel een aantal veranderingen voor zorgprofessionals met zich mee in de manier van werken, en daarmee in de (balans tussen) werkeisen en energiebronnen. In de eerste plaats leidt gezamenlijke besluitvorming ertoe dat een deel van het werk wordt verdeeld tussen professional en patiënt. Enerzijds kan dit voor de betreffende professional een verlichting van werkeisen betekenen, omdat een deel van de verantwoordelijkheden wordt gedeeld. Uiteraard blijft de zorgprofessional wel eindverantwoordelijk voor de uiteindelijke beslissing. Anderzijds kan het een effect hebben op de autonomie van de zorgprofessional. Autonomie betreft de mogelijkheid om zelf beslissingen te nemen over de manier waarop het werk wordt uitgevoerd en om problemen op te lossen. Dit is een belangrijke energiebron om te hoge werkdruk te voorkomen. Bij gezamenlijke besluitvorming wordt een deel van de zelfstandigheid om beslissingen te nemen gedeeld met de patiënt. Dat zou tot een beperking van de autonomie van de professional kunnen leiden. Daar staat tegenover dat de samenwerking met de patiënt toeneemt en er een sterkere interactie plaatsvindt om tot betere (beter passende) beslissingen te komen (Butcher, 2013). Ook het gebruik van een keuzehulp vergroot de interactie (Marrin et al., 2014). Interactie, de mogelijkheid om over het werk af te stemmen met anderen, wordt als een energiebron gezien.

Een andere energiebron voor zorgprofessionals is patiënttevredenheid. Als patiënten tevreden zijn over de zorg en het zorgproces, dan heeft dat positieve gevolgen voor zorgprofessionals, met name in termen van werktevredenheid (Casalino \& Crosson, 2015; Firth-Cozens, 2015). Als gezamenlijke besluitvorming bijdraagt aan patiënttevredenheid, zoals aangetoond in studies van Butcher (2013), Edwards en Elwyn (1999), O'Connor et al. (1999) en Stiggelbout et al. (2015), dan kan dat ook een energiebron voor de zorgprofessional zijn en bijdragen aan het omgaan met werkeisen.

Met betrekking tot werkeisen kan het gebruik van gezamenlijke besluitvorming leiden tot langere en/of meerdere consulten. Om alle fasen van de gezamenlijke besluitvorming zorgvuldig en expliciet te doorlopen is er meer tijd nodig om informatie te delen, opties te bespreken, voor- en nadelen af te wegen, en keuzes te maken in samenspraak met de patiënt. Hierdoor kunnen er minder patiënten tijdens het spreekuur terecht. Het kan er ook voor zorgen dat behandelaars meer tijd nodig hebben om een consult voor te bereiden, omdat ze (argumenten voor) meerdere opties moeten voorbereiden. Daar staat tegenover dat patiënten minder second opinions aanvragen en minder vervolgbehandelingen nodig hebben (Stiggelbout et al., 2015), wat tot kortere wachtlijsten leidt.

Het proces van gezamenlijke besluitvorming vergt ook meer flexibiliteit van de behandelaar in het komen tot een behandelplan. In een situatie waarin de behandelaar zelf het behandelplan vaststelt kan hij/zij meer vanuit een medische rationaliteit tot een besluit komen. Bij gezamenlijke besluitvorming is er meer sprake 
van maatwerk en moet nadrukkelijk de voorkeur van de patiënt worden meegewogen. Dat gebeurt wellicht nu ook al steeds meer, maar bij gezamenlijke besluitvorming is het ook van belang dat patiënten op verschillende manieren met het besluitvormingsproces om kunnen gaan. Ook hier moet de zorgprofessional op inspelen en rekening mee houden. De persoonlijkheid van een patiënt, met name zelfeffectiviteit (het vertrouwen in de eigen bekwaamheid; self-efficacy), is in grote mate bepalend voor de betrokkenheid van die patiënt in het gezamenlijke besluitvormingsproces (Hagbaghery, Salsali, M., \& Ahmadi, 2004). Ook culturele achtergrond, gezondheidsgedrag en karakter kunnen hierbij een rol spelen. Deze verschillen vergen aandacht en flexibiliteit van de behandelaar en dragen dus bij aan de werkeisen.

Op basis van voorgaande redeneringen is er geen duidelijke conclusie te trekken over de wijze waarop gezamenlijke besluitvorming effect heeft op werkdruk. Het kan leiden tot een vermindering van de energiebron autonomie, maar anderzijds ook tot meer energiebronnen in de vorm van meer interactie en hogere patiënttevredenheid. Ook in termen van werkeisen kan gezamenlijke besluitvorming op verschillende manieren een effect hebben. Enerzijds kan het tot meer en langere consulten leiden en vergt het meer flexibiliteit en inlevingsvermogen van de zorgprofessional, anderzijds kan het juist ook leiden tot minder verzoeken om second opinions en vervolgbehandelingen.

Of en welke gevolgen gezamenlijke besluitvorming heeft voor de werkeisen, energiebronnen en werkdruk van zorgprofessionals is verder afhankelijk van de manier waarop de implementatie plaatsvindt, in welke mate de veranderingen in het werk in de organisatie van dat werk worden meegenomen, en van de verschillen tussen patiënten. Er zijn wel voorgeschreven stappen om gezamenlijke besluitvorming vorm te geven (Elwyn et al., 2013; Stiggelbout et al., 2015), maar dat zegt niets over de manier waarop dat doorwerkt in de organisatie van het werk, en daarmee in de (balans tussen) werkeisen en energiebronnen. Er zijn verschillende manieren om het gebruik van gezamenlijke besluitvorming te stimuleren, maar ook hier zijn er geen eenduidige conclusies over welke manier het beste werkt (Légaré et al., 2018). Dat maakt het lastig om op voorhand duidelijke verwachtingen te formuleren over het effect van gezamenlijke besluitvorming op de werkdruk van zorgprofessionals. Daarom heeft dit onderzoek een exploratief karakter en gebruiken we de theoretische lens van werkeisen en energiebronnen als 'sensitizing concepts' voor het empirische deel van ons onderzoek. In de volgende paragraaf leggen we de methodologische keuzes in dit onderzoek verder uit.

\section{Methode}

Om te onderzoeken welke effecten voor werkdruk de invoering van gezamenlijke besluitvorming kan hebben, hebben we een exploratief kwalitatief onderzoek uitgevoerd bij de afdeling urologie van een Nederlands topklinisch ziekenhuis. Binnen deze afdeling was 'Samen beslissen' ingevoerd als vorm van gezamenlijke besluitvorming tussen behandelaar en patiënt. We konden het gezamenlijke besluitvormingsproces van tien met prostaatkanker gediagnosticeerde patiënten 
volgen. Hierbij waren twee zorgprofessionals betrokken: een uroloog en een verpleegkundig specialist. Alle patiënten en zorgprofessionals zijn geïnterviewd. Daarvoor hebben ze schriftelijk toestemming gegeven onder de conditie van volledige anonimiteit. Daarnaast heeft de manager van de afdeling urologie toestemming gegeven voor het onderzoek. Het onderzoeksvoorstel is tevens voorgelegd aan de 'Commissie Mensgebonden Onderzoek' om te toetsen of het onderzoek onderhevig was aan de 'Wet Medisch-Wetenschappelijk Onderzoek'. Dat bleek niet het geval te zijn. Ten slotte heeft ook het 'Research Support Office' van het ziekenhuis toestemming gegeven voor het onderzoek.

\subsection{Context}

Het ziekenhuis heeft de ambitie de juiste (waardevolle) zorg op de juiste plek te leveren en daar patiënten actief bij te betrekken. De missie is om patiënten te behandelen als unieke personen met individuele wensen en behoeften. Daarbij past het om patiënten actief in het besluitvormingsproces rondom behandelplannen te betrekken. Daartoe is het project 'Samen beslissen' ontwikkeld. In oktober 2017 is de afdeling urologie begonnen met het gebruik van de keuzehulp voor patiënten met behandelbare prostaatkanker. Voor de behandeling van patiënten die met prostaatkanker zijn gediagnosticeerd, zijn er verschillende behandelopties. Dat biedt mogelijkheden tot het maken van verschillende keuzes in het behandelproces. Dat maakt deze gezamenlijke besluitvormingsprocessen geschikt voor dit onderzoek. Als patiënten niet echt verschillende opties hebben om keuzes te maken, dan is er niet echt sprake van gezamenlijke besluitvorming.

Als patiënten zijn gediagnosticeerd met prostaatkanker, krijgen ze toegang tot een online keuzehulp. Deze keuzehulp bevat informatie over prostaatkanker en over de verschillende behandelmethoden (operatie, bestraling, geen behandeling) met voor- en nadelen van elke behandeling. Daarnaast bevat de keuzehulp een aantal vragen aan de patiënt over diens voorkeuren. Na ongeveer twee weken heeft de patiënt een afspraak met de verpleegkundig specialist. Tijdens deze afspraak bespreken patiënt en verpleegkundig specialist de keuzehulp, de daarin gepresenteerde informatie over prostaatkanker en de verschillende behandelmethoden, en de voorkeuren van de patiënt. Na deze afspraak vindt er een multidisciplinair medisch overleg plaats met al het betrokken medisch personeel (zoals uroloog, verpleegkundig specialist, radioloog, etc.) over de specifieke situatie per patiënt, diens voorkeuren en de mogelijke behandelmethoden. Daarna komen patiënt en uroloog tijdens een volgend consult tot de keuze van de best passende behandelmethode bij deze specifieke patiënt.

\subsection{Dataverzameling}

Om inzicht te krijgen in de manier waarop 'Samen beslissen' wordt uitgevoerd, hoe betrokkenen het proces ervaren, en wat de effecten zijn op de werkdruk van zorgprofessionals hebben we diepte-informatie verzameld via half-gestructureerde interviews met alle patiënten en de twee professionals die hierbij betrokken waren. Patiënten zijn na het keuzeconsult met de uroloog geïnterviewd, zodat ze over hun ervaringen met het hele gezamenlijke besluitvormingsproces konden vertellen. De open vragen hadden betrekking op hun ervaringen met het besluit- 
vormingsproces (keuzehulp en gesprekken), in welke mate ze de gezamenlijke besluitvorming hebben ervaren (en de verschillende fasen daarin), hoe tevreden ze daarover zijn, en welke onderdelen in het proces met name van invloed zijn op de tevredenheid. Als checklist werden ook enkele meer gerichte vragen op basis van de literatuur opgesteld. Deze vragen werden alleen gesteld als de onderwerpen daarvan bij de antwoorden op de open vragen nog niet aan bod kwamen. Deze vragen hadden met name betrekking op specifieke onderwerpen waarvan uit de literatuur bleek dat ze van invloed zouden kunnen zijn op de tevredenheid van de patiënten. Voorbeelden hiervan zijn: de mate waarin er rekening werd gehouden met hun voorkeuren (Stacey et al., 2017; Stiggelbout et al., 2015), de kosten van de zorg (Butcher, 2013), het zelfvertrouwen van de patiënt (Elwyn et al., 2013), de verwachte gezondheidsuitkomsten (Benbassat et al., 1998; Stiggelbout et al., 2015), de relatie met de arts (Stiggelbout et al., 2015), en de verkregen informatie en kennis (Elwyn et al., 2012; Stacey et al., 2017). Daarnaast zijn er demografische gegevens verzameld, zoals leeftijd, opleidingsniveau en burgerlijke staat. Tabel 1 geeft een overzicht van de verzamelde demografische gegevens. Alle patiënten zijn Nederlandse mannen en ze hebben allemaal een partner. Ze verschillen naar leeftijd en opleidingsniveau.

\section{Tabel 1 Demografische kenmerken van de patiënten in het onderzoek}

\begin{tabular}{lllll}
\hline Patiënt & $\begin{array}{l}\text { Leef- } \\
\text { tijd }\end{array}$ & Nationaliteit & Burgerlijke staat & $\begin{array}{l}\text { Hoogst afgeronde } \\
\text { opleiding }\end{array}$ \\
\hline 1 & 57 & NL & Gehuwd & universiteit \\
2 & 57 & NL & Gehuwd & hbo \\
3 & 63 & NL & Geregistreerd partnerschap & hbo \\
4 & 72 & NL & Gehuwd & mbo \\
5 & 66 & NL & Gehuwd & mbo \\
6 & 66 & NL & Gehuwd & hbo \\
7 & 70 & NL & Gehuwd & lbo \\
8 & 62 & NL & Gehuwd & hbo \\
9 & 70 & NL & Gehuwd & mbo \\
10 & 63 & NL & Gehuwd & mbo \\
\hline
\end{tabular}

Noot. $\mathrm{Hbo}=$ hoger beroepsonderwijs, $\mathrm{mbo}=$ middelbaar beroepsonderwijs, lbo = lager beroepsonderwijs.

De zorgprofessionals zijn na afloop van de tien besluitvormingsprocessen geïnterviewd. Vanwege de tijd die er tussen de verschillende processen zat (de totale doorlooptijd was vijf maanden in de zomer en het najaar van 2018 om tot een totaal van tien patiënten te komen), hebben de zorgprofessionals meteen na elk consult met de betreffende patiënten een korte vragenlijst ingevuld. De uitkomsten daarvan dienden als input voor de interviews en als geheugensteun voor de professionals om de besluitvormingsprocessen met de verschillende patiënten te kunnen onderscheiden. In deze vragenlijst werden vragen en stellingen voorgelegd over het proces en de ervaring van de zorgprofessionals, onder andere gebaseerd 
op de verschillende fasen in het gezamenlijke besluitvormingsproces (Elwyn et al., 2012; Stiggelbout et al., 2015). Voorbeeldvragen zijn: Heeft u 'Samen beslissen' toegepast tijdens dit consult? Ik heb mijn patiënt duidelijk gemaakt dat er een beslissing moet worden genomen. Ik heb de patiënt gevraagd welke behandelingsmogelijkheid zijn voorkeur heeft. De patiënt en ik hebben de verschillende behandelingsmogelijkheden grondig afgewogen. Hoe ging het 'Samen beslissen' tijdens dit consult?

Tijdens de half-gestructureerde interviews met de zorgprofessionals zijn open vragen gesteld over de ervaringen met 'Samen beslissen', de kwaliteit en het gebruik van de keuzehulp, de mate waarin en wijze waarop invulling is gegeven aan de gezamenlijke besluitvorming, en de effecten van 'Samen beslissen' voor de kwaliteit van de zorg, de manier van werken, de interactie met de patiënt, en de werkdruk. Ook hier fungeerden meer specifieke vragen als checklist voor onderwerpen die in de antwoorden op de open vragen nog niet aan bod waren gekomen. Hierbij kwamen de in het theoretisch kader genoemde werkeisen (voorbereiding consulten, lengte consulten, intensievere consulten, afstemming op individuele patiënten) en energiebronnen (autonomie, patiënttevredenheid, interactie met patiënten) aan bod. Bijvoorbeeld, voor werkdruk is de volgende open vraag geformuleerd: Is samen beslissen van invloed op de werkdruk? Als topics voor eventuele vervolgvragen over het effect op werkdruk zijn de volgende onderwerpen in het interviewprotocol opgenomen: meer tijd om consult voor te bereiden, omdat meer scenario's moeten worden uitgewerkt; consulten duren langer vanwege toegenomen consultatie en argumentatie; meer consulten; meer moeite doen om patiënten te overtuigen; intensivering van het werk door meer interactie met patiënt.

\subsection{Data-analyse}

De uitgewerkte en getranscribeerde interviews en vragenlijsten zijn deductief (op basis van vooraf bepaalde codes) en inductief (op basis van open en niet vooraf bepaalde codes die uit de transcripten zijn gedestilleerd) geanalyseerd. Ook de antwoorden op de open vragen in de vragenlijst die de professionals na elk consult invulden, zijn hierin meegenomen. Naar aanleiding van de onderwerpen in het theoretisch kader zijn deductieve codes bepaald om te achterhalen op welke wijze en in welke mate 'Samen beslissen' werd toegepast. Er is gekeken welke fasen expliciet konden worden onderscheiden, hoe tevreden de patiënten waren en welke factoren daaraan bijdroegen, hoe de professionals het proces ervoeren en welke effecten dat heeft op werkdruk in termen van werkeisen en energiebronnen. Om te bestuderen of er ook andere dan in het theoretisch kader genoemde zaken een rol spelen, zijn de transcripten ook inductief gecodeerd. Op basis hiervan kwamen andere mogelijke verklaringen en interpretaties voor de werkdruk van de zorgprofessionals aan het licht. Dit doet recht aan het exploratieve karakter van deze studie. De resultaten hiervan bespreken we in de volgende paragraaf. 


\section{Resultaten}

\subsection{Ervaringen patiënten: bevestiging positieve effecten}

'Samen beslissen' is bij elke patiënt expliciet toegepast en alle patiënten hebben aangegeven actief in het besluitvormingsproces te zijn betrokken. Er zijn wel verschillen in de mate waarin de patiënten de term 'Samen beslissen' herkennen en erkennen. Eén patiënt heeft aangegeven uiteindelijk niet echt een keuze te hebben gehad, omdat uit een vervolgonderzoek bleek dat er maar één behandeloptie over bleef. Maar ook bij deze patiënt is actief en expliciet het gezamenlijke besluitvormingsproces in gang gezet; de patiënt is geïnformeerd over de verschillende opties en de voor- en nadelen zijn afgewogen. Enkele andere patiënten geven aan dat de mening van de zorgprofessional voor hen erg belangrijk is en daardoor de uiteindelijke beslissing sterk daarop baseren.

In lijn met eerdere studies zijn de ervaringen van de patiënten met 'Samen beslissen' overwegend (zeer) positief. Geen enkele patiënt rapporteerde negatieve effecten of nadelen van het gezamenlijke besluitvormingsproces. Om dit te onderstrepen gebruiken de patiënten termen als plezierig, open, transparant, constructief, goed, helder, belangrijk, gemakkelijk, bruikbaar, betrokken, respectvol, waardevol en essentieel. De tevredenheid van de patiënten strekt zich uit over alle fasen in het besluitvormingsproces. De mogelijkheid om zelf een keuze te mogen maken, de geboden informatie via keuzehulp en consulten, de betrokkenheid in het besluitvormingsproces, en het bepalen van een eigen voorkeur werden zeer gewaardeerd. Hoewel sommige patiënten ook op de expertise van de zorgprofessional zouden vertrouwen om tot een behandeling te komen, waarderen ze wel de mogelijkheid om zelf een voorkeur te ontwikkelen en de openheid in het hele traject. De volgende citaten zijn kenmerkend voor deze gevoelens.

Alles was bespreekbaar, alle mogelijkheden waren bespreekbaar. Er waren geen drempels, je kon ook alles vragen (patiënt \#3).

Die informatie is heel erg belangrijk natuurlijk want anders kun je niet samen beslissen. Want de arts heeft alle kennis en zelf heb je wel wat kennis natuurlijk maar je weet nooit het fijne ervan. Daar heb je die arts voor nodig (patiënt \#9).

Je wordt overal in betrokken dan en dat vind je natuurlijk belangrijk als je iets ernstigs hebt. Die arts is er uiteindelijk dan ook bij betrokken en dat geeft toch een ander gevoel dan. Het is dan niet zo afstandelijk (patiënt \#9).

Daarnaast ervaren de patiënten een duidelijke ondersteuning en bevestiging van hun keuzes. Zowel de keuzehulp als de consulten met de zorgprofessionals zijn daarbij van belang, hoewel er ook patiënten waren die de keuzehulp nog te beperkt vonden. Maar de meesten zijn heel tevreden over de open en transparante manier waarop de verschillende opties met elkaar zijn afgewogen om tot een keuze te komen, zoals blijkt uit de volgende citaten. 
En de manier waarop dit proces dan loopt, dat je daarmee gekend wordt in de afweging en dilemma's die het team zelf heeft, dat vind ik heel waardevol en dat leidt tot een tevreden gevoel over het proces (patiënt \#1).

Het was natuurlijk wel goed dat die arts bevestigt dat dat de beste oplossing is. Dus dat geeft wel een gevoel van tevredenheid. Omdat je dan voor jezelf het idee hebt van nou ik heb dan toch de goede keuze gemaakt (patiënt \#2).

Nou, dat heeft te maken met dat stuk geruststelling wat je gekregen hebt door die keuzehulp en door het op die manier met elkaar te bespreken (patiënt \#8).

Ook de patiënt die aangaf uiteindelijk niet echt een keuze te hebben gehad, is tevreden over de wijze waarop hij is geïnformeerd en de openheid in het hele besluitvormingsproces.

Daarnaast ervaren de patiënten het proces als efficiënt en vergroot het hun vertrouwen in een goede afloop. Ook dit is voornamelijk een bevestiging van eerdere studies naar de effecten van gezamenlijke besluitvorming op de beleving van het zorgproces door patiënten.

\subsection{Ervaring zorgprofessionals: minder werkdruk}

Over het algemeen zijn de uroloog en verpleegkundig specialist zeer tevreden over 'Samen beslissen'. Ze benadrukken hierin de goede en intensieve interactie met de patiënten die 'Samen beslissen' met zich meebrengt. Ook het feit dat patiënten beter geïnformeerd zijn en dat patiënten tevreden zijn over dit proces, draagt bij aan de tevredenheid van de zorgprofessionals. In termen van werkdruk (balans werkeisen en energiebronnen) geven ze eveneens vooral positieve ervaringen weer. Verder blijkt uit de interviews dat met name enkele contextuele kenmerken in de organisatie bijdragen aan de positieve ervaringen wat betreft werkdruk. Hieronder bespreken we de verschillende ervaringen met betrekking tot werkeisen en energiebronnen, en de contextuele kenmerken die daaraan bijdragen.

\section{- Werkeisen}

De zorgprofessionals geven aan dat de voorbereiding van de consulten niet meer tijd vraagt dan anders. De consulten zijn wel langer, maar daar wordt in de planning rekening mee gehouden. Ook de intensievere interactie met de patiënten zorgt niet voor een intensivering van het werk. Evenmin hoeft er meer energie te worden gestoken in het overtuigen van de patiënten. Sterker nog, de uroloog geeft aan dat de beter geïnformeerde patiënten juist energie geven. En de verpleegkundig specialist vult aan dat dit ook zorgt voor minder ad hoc vragen tijdens de consulten. Volgend citaat geeft dit weer.

Ja de beter geïnformeerde patiënt en dat je daardoor op een beter niveau van gedachten kan wisselen, dat maakt de inhoud van de consulten leuker (Uroloog).

Daarnaast geven de professionals aan dat de keuzehulp een deel van de informatieverstrekking van hen overneemt, wat voor een verlichting van de werklast zorgt. 
Het is prettig te werken met mensen, patiënten, die een beetje weten waar ze het over hebben als je beslissingen moet nemen. En bij prostaatkanker zijn er beslissingen te nemen, dat is voor sommige aandoeningen natuurlijk anders. Maar er zijn echt keuzes te maken die ook op inhoud relevant verschillend zijn zeg maar. Als je die keuzes met mensen moet maken, is het prettig als ze goed geïnformeerd zijn (Uroloog).

De professionals erkennen wel dat verschillen tussen patiënten in termen van persoonlijkheid, opleidingsniveau en leeftijd ervoor zorgen dat ze elk proces op de individuele patiënt moeten afstemmen. Sommige patiënten staan er echt voor open om in de besluitvorming betrokken te worden, terwijl andere daar terughoudend in zijn. Hoewel de professionals proberen iedereen actief bij de besluitvorming te betrekken, merken ze dat niet elke patiënt daar open voor staat.

Je kan ze natuurlijk altijd tot op zekere hoogte proberen te betrekken maar dat is niet per definitie altijd succesvol (Uroloog).

Sommige patiënten weten goed wat ze willen en geven dat ook aan. Andere patiënten hebben meer moeite om een eigen voorkeur te ontwikkelen en hebben meer hulp nodig. Volgens de verpleegkundig specialist vormen patiënten in deze laatste groep de grootste uitdaging om hen er toch bij te betrekken. De besluitvorming gaat makkelijker als de patiënten zich goed voorbereiden, duidelijk zijn in hun voorkeuren en de verschillende opties goed hebben doordacht. Er is meer uitdaging als de patiënten twijfelen en moeite hebben tot een keuze te komen. Daarbij zien de professionals ook verschillen naar leeftijd. Oudere patiënten zijn vaak meer gewend dat een behandelaar besluit wat het beste is. Jongere patiënten zijn daardoor volgens de verpleegkundig specialist vaker meer betrokken in het besluitvormingsproces dan ouderen. Ook zien de professionals dat hoger opgeleiden vaker meer in het besluitvormingsproces betrokken willen zijn. Lager opgeleiden hechten vaker meer waarde aan de mening van de behandelaar en vinden het ook prettiger als deze zegt wat de beste behandeling is.

\section{- Energiebronnen}

Volgens de zorgprofessionals zorgt 'Samen beslissen' niet voor een aantasting van hun autonomie. De verpleegkundig specialist geeft aan dat hij geen operaties uitvoert en daardoor heeft een besluit voor de behandeling (ongeacht door wie het besluit genomen is) geen directe invloed op zijn werk. De uroloog geeft aan dat zijn professionele autonomie niet wordt aangetast doordat hij geen behandelingen uitvoert waar hij niet achter staat. Als een patiënt voor een behandeling kiest waar de uroloog niet achter staat, dan wordt deze patiënt doorverwezen naar een andere uroloog.

Daarnaast geeft de verpleegkundig specialist aan dat zijn autonomie behoorlijk hoog is, omdat hij de patiënten volledig informeert en voorbereidt op het maken van een keuze. In dat proces kan hij zelf zijn consulten met de patiënten plannen en kan hij het zorgproces voor verschillende patiënten zelf managen. 
Dat ik zelf mijn eigen spreekuur heb en dus kortom zelf kan plannen, zelf de regie heb hoe het met de patiënten gaat en dat ze dus ook altijd terug kunnen vallen op mij, als een soort casemanager (Verpleegkundig specialist).

Voor de uroloog is de autonomie vooral gelegen in de mogelijkheden om de beste behandeling voor een patiënt te bieden. Daartoe moet hij zorgvuldig nadenken over de problemen per patiënt, hoe deze op te lossen en uiteindelijk de oplossing uit te voeren. Daarbij ervaart hij in elke stap voldoende autonomie en controle over de gang van zaken, ook al komt de uiteindelijke beslissing tot stand in samenspraak met de patiënt.

Ik heb op geen enkele manier het gevoel dat ik geen controle of autonomie heb (...) Ik denk dat de behoefte erin zit dat ik voor iemand de juiste passende oplossing aandraag. En met 'samen beslissen' is de kans groter dat de oplossing passend is. Dan is het misschien niet de behandeling die ik voor mezelf zou kiezen maar die wel bij degene past die tegenover mij zit. Dus dat doet niks met mijn controle en autonomie; die gaat over de juiste behandeling aanbieden (Uroloog).

Een andere belangrijke energiebron voor de zorgprofessionals is het interactiepotentieel. Beide professionals geven aan dat 'Samen beslissen' een sterk positieve invloed heeft op de hoeveelheid en kwaliteit van de interactie tussen behandelaar en patiënt. Zoals eerder aangegeven, zorgt dit ook voor minder belastende werkeisen. Patiënten die beter geïnformeerd zijn over de aandoening, de verschillende behandelopties en de mogelijke risico's van de behandelingen, maken het werk interessanter en leuker. De keuzehulp speelt een belangrijke rol in het informeren van de patiënten ter verbetering van de interactie.

Ja, maar wat vooral zo is, is dat er verschillende manieren van interactie zijn. Stel nou voor dat je niet die keuzehulp zou hebben. (...) Maar nu wordt het ook visueel gemaakt op de computer, dus je hebt verschillende manieren van informatie verstrekken eigenlijk wat je aan het doen bent, en op andere manieren, mensen kunnen op een tablet kijken of op een computer. (...) Ik geloof heel erg erin dat je verschillende vormen van informatievoorziening moet hebben: a) voor de verschillende groepen, maar b) ook gewoon überhaupt om het gevarieerd aan te bieden en dat de patiënt het ook gevarieerd leest. Dat leidt ook tot betere interactie en dat merk ik ook in mijn spreekkamer dan, want de patiënten zijn beter voorbereid en dat is veel fijner praten. Als patiënten voorbereid zijn en weten waar ze het over hebben dan heb je het echt over de belangrijkere vragen dan algemene uitleg (Verpleegkundig specialist).

Verder blijkt uit de interviews dat de professionals de patiënttevredenheid ook als een energiebron ervaren, wat bijdraagt aan een positieve interpretatie van de werkdruk. De professionals denken dat 'Samen beslissen' voor meer tevreden patiënten zorgt, en dat zorgt voor meer voldoening bij hen. De verpleegkundig specialist streeft naar tevreden patiënten en 'Samen beslissen' is daarin een nuttig hulpmiddel. De voldoening bestaat er dan uit om patiënten zo goed mogelijk door het proces te loodsen. 
Mijn doel is om patiënten zo goed mogelijk te begeleiden, ook eigenlijk in het proces naar de behandeling en daarna. Ja ik wil heel graag dat zij tevreden zijn, want dan ben ik het eigenlijk ook (Verpleegkundig specialist).

De uroloog geeft aan dat tevreden patiënten minder belastend zijn, wat zorgt voor een betere werkdrukbalans.

Nou de wens is dat ik hoop dat ik tevredener patiënten heb en dat maakt mijn werk natuurlijk leuker want een tevreden patiënt is leuker om mee te werken dan een boze patiënt of een ontevreden patiënt, dus dat is winst (Uroloog).

Hiermee is patiënttevredenheid als energiebron nadrukkelijk persoonsafhankelijk. Beide zorgprofessionals streven naar een hoge patiënttevredenheid. Voor iemand die daar niet naar streeft, zal patiënttevredenheid niet/minder als energiebron gelden. Overigens laat het citaat van de uroloog ook zien dat als patiënten boos of ontevreden zijn, het wel als een werkeis aangemerkt kan worden.

\section{- Contextuele kenmerken}

Uit de interviews met de zorgprofessionals bleek dat, naast bovenstaande werkeisen en energiebronnen, een aantal contextuele kenmerken rondom de implementatie van 'Samen beslissen' van belang zijn voor de werkdruk. Twee kenmerken springen eruit: de taakverdeling (functieontwerp) en de planning van de spreekuren.

Bij de implementatie van 'Samen beslissen' heeft de organisatie bewust gekozen voor een specifieke verdeling van taken tussen uroloog en verpleegkundig specialist, waardoor de balans tussen werkeisen en energiebronnen voor beide functies in evenwicht is en zorgt voor uitdagende functies en positieve uitkomsten. Het beslis- en behandelproces is in twee delen gesplitst. Nadat een patiënt met prostaatkanker is gediagnosticeerd, wordt het voorbereidende deel uitgevoerd door de verpleegkundig specialist. Deze voorziet de patiënt van de noodzakelijke informatie en begeleidt de patiënt bij het bepalen van de voorkeuren. Het uiteindelijke besluit wordt genomen in samenspraak tussen uroloog en patiënt. De verpleegkundig specialist heeft en voelt de verantwoordelijkheid voor dit voorbereidend traject. Daarin heeft hij voldoende autonomie om het proces naar eigen inzicht en afgestemd op de individuele patiënt uit te voeren; hij geeft aan daarin zelf de regie te voeren. De geschetste verdeling van taken zorgt voor de uroloog voor een beperking van de werkbelasting, want hij hoeft zich alleen te bemoeien met het uiteindelijke besluit, samen met goede voorbereide patiënten.

Het tweede kenmerk dat de implementatie van 'Samen beslissen' in deze organisatie succesvol maakt, is het feit dat er in de planning van de spreekuren rekening wordt gehouden met de langere tijd die de verschillende gesprekken in beslag kunnen nemen. Voor de behandelgesprekken waarin veel informatie moet worden gedeeld en besproken en waarin patiënten uitgebreid vragen kunnen stellen, worden langere consulten ingepland, waardoor de behandelaars met voldoende rust de patiënten te woord kunnen staan. Ze ervaren dan geen druk van oplopende wachttijden voor andere patiënten. 
Ik vind zoals mijn poli er nu uitziet met spreekuur slots waarin ik de tijd heb om beslissingen te nemen met mensen, dat is voor mezelf ook rustiger. Poli spreekuren met allemaal slots van 5 of 10 minuten dat is gewoon keihard werken en ik wil niet zeggen dat je er minder moe van wordt maar het is wel een andere manier van werken (Uroloog).

De bewuste keuzes in het functieontwerp en de werkorganisatie maken dat 'Samen beslissen' in deze organisatie bijdraagt aan het niet laten toenemen van de werkeisen (werklast) en het bevorderen van de energiebronnen (met name autonomie).

\section{Conclusie en discussie}

Ons exploratief onderzoek naar de mechanismen die verklaren of en waarom gezamenlijke besluitvorming leidt tot meer of minder werkdruk in het zorgproces van prostaatkankerpatiënten, laat zien dat zowel patiënten als zorgprofessionals de gezamenlijke besluitvorming in deze casus zeer positief ervaren. De inhoud, vormgeving en organisatie van 'Samen beslissen' in de onderzochte organisatie leiden tot een goede balans tussen werkeisen en energiebronnen, en daarmee tot een goed hanteerbare werkdruk bij de betrokken zorgprofessionals. De inhoud van 'Samen beslissen', met een belangrijke rol voor de keuzehulp, zorgt ervoor dat patiënten van de juiste informatie en ondersteuning worden voorzien om actief in de besluitvorming te participeren. Daardoor worden besluiten genomen waar patiënt en behandelaar tevreden over zijn. Omdat patiënten goed worden geïnformeerd, via keuzehulp en verpleegkundig specialist, kunnen besluiten op een efficiënte manier worden genomen en ervaren de professionals geen extra werkbelasting door het gezamenlijke besluitvormingsproces. Ook tast deze manier van besluitvorming de autonomie van de zorgprofessionals niet aan. Zowel de verpleegkundig specialist als de uroloog ervaart veel autonomie en regie over het werk dat ze (moeten) doen.

Bij de implementatie van 'Samen beslissen' in deze organisatie is de andere manier van werken expliciet in de taakverdeling meegenomen. De verpleegkundig specialist is verantwoordelijk voor de voorbereiding op het nemen van het besluit. De uroloog is verantwoordelijk voor het nemen van het besluit, in samenspraak met de patiënt, en het vervolg daarvan (behandeling). Door de verpleegkundig specialist verantwoordelijk te maken voor de uitvoering van een geheel en afgerond voorbereidend traject heeft deze een zogenaamd 'volledige functie' (Hacker, 1989). Het hebben van een volledige functie is, volgens de WEBA-methode (Christis, 1999) een van de voorwaarden voor een goede balans tussen werkeisen en energiebronnen. Voor de uroloog betekent deze verdeling van taken eveneens een goede balans, omdat een aantal werkverzwarende taken rondom 'Samen beslissen' niet bij hem, maar bij de verpleegkundig specialist zijn ondergebracht. Zo is bij beide functies een takenpakket ondergebracht met passende verantwoordelijkheden met bijbehorende bevoegdheden.

Meer praktisch heeft de aanpalende maatregel om bij de planning van de gesprekken in het kader van 'Samen beslissen' extra tijd in te plannen ook gunstige effec- 
ten op de werkdruk van de professionals. Door bij de implementatie van de gezamenlijke besluitvorming de consequenties daarvan voor het tijdsbeslag van consulten expliciet in ogenschouw te nemen en er rekening mee te houden bij het plannen van consulten zijn de werkdrukeffecten gunstig (in die zin dat de werkdruk niet toeneemt).

Op basis hiervan kunnen we concluderen dat gezamenlijke besluitvorming niet alleen leidt tot een hogere tevredenheid bij patiënten, zoals ook in andere studies al is aangetoond (Benbassat et al., 1998; Butcher, 2013; Griffin et al., 2004; Guadagnoli \& Ward, 1998; Stacey et al., 2017; Stiggelbout et al., 2015), maar dat het ook gunstige effecten kan hebben voor zorgprofessionals. Enerzijds zijn die gunstige effecten te relateren aan de interactie tussen professional en patiënt, omdat patiënttevredenheid een gunstig effect heeft op de beleving van professionals en daarmee als een energiebron kan fungeren (Casalino \& Crosson, 2015; Firth-Cozens, 2015). Anderzijds zijn die gunstige effecten te relateren aan de zorgvuldigheid waarmee een dergelijke andere manier van werken wordt ingevuld en geïmplementeerd. Een verandering in de manier van werken die gepaard gaat met een functieontwerp gericht op volledige functies (met een goede balans tussen werkeisen en energiebronnen) en bijpassende aanpalende maatregelen in de organisatie van het werk, kan gunstige effecten hebben voor de werkdruk, zelfs in een sector die kampt met hoge werkdruk.

Enige terughoudendheid in de conclusies is op zijn plaats, vanwege een aantal beperkingen in dit onderzoek. In de eerste plaats laat ons exploratief onderzoek geen vergelijking in de tijd of met andere situaties toe. Ten tijde van het onderzoek was 'Samen beslissen' al enige tijd ingevoerd in deze afdeling. We hebben alleen kunnen kijken naar de huidige werkdruk. We hebben niet kunnen achterhalen of de werkdruk voor de zorgprofessionals als gevolg van 'Samen beslissen' was veranderd, omdat de betrokken professionals niet op een meer traditionele manier hebben gewerkt. Derhalve kunnen er geen causale conclusies worden getrokken. Ook is er geen vergelijking met een controlegroep waarin niet met gezamenlijke besluitvorming wordt gewerkt. Vervolgonderzoek zou zich kunnen richten op een longitudinaal design om met meer zekerheid de gevonden mechanismen (verankering van gezamenlijke besluitvorming in het functieontwerp en expliciete inbedding in de organisatie en planning van het werk) te testen.

In de tweede plaats kunnen we niet concluderen dat gezamenlijke besluitvorming bij elk medisch specialisme of elke gediagnosticeerde aandoening tot gunstige effecten leidt. Van belang is in ieder geval dat er daadwerkelijk wat te kiezen valt en dat de patiënt (in dit geval alleen mannen met prostaatkanker) daar zinvol in kan participeren. Bij acute aandoeningen waar snel een besluit moet worden genomen, zal een dergelijk zorgproces niet werken en wellicht zelfs negatieve effecten hebben, zowel voor de patiënt als voor de werkdruk van de zorgprofessional. In die zin was de setting van deze studie gunstig om met gezamenlijke besluitvorming aan de slag te gaan, hetgeen ook de overwegend positieve reacties van zowel patiënten als professionals kan verklaren. Onderzoek in andere situaties (andere aandoeningen, andere populatie patiënten) kan meer nuance geven in de gevonden mechanismen. In de derde plaats zijn het aantal en de diversiteit van de betrokken zorgprofessionals in dit onderzoek zeer beperkt. De zorgprofessionals in dit onderzoek staan 
zeer positief tegenover 'Samen beslissen', omdat het goed aansluit bij hun attitudes in het zorgproces en het leveren van goede zorg. Onderzoek, zo mogelijk kwantitatief, in een grotere en meer diverse populatie van zorgprofessionals kan meer inzicht bieden in de rol die zorgverlenerskenmerken spelen in de relatie tussen gezamenlijke besluitvorming en werkdruk van zorgprofessionals.

Ondanks deze tekortkomingen in het huidige exploratieve onderzoek zijn de resultaten hoopgevend en nodigen zij uit tot vervolgonderzoek waarin de gevonden mechanismen nader kunnen worden getoetst. Het kader van werkeisen en energiebronnen (Demerouti et al., 2001; Karasek, 1979) is daarbij zinvol gebleken.

\section{Praktische implicaties}

De resultaten van dit onderzoek sluiten ook aan bij de actuele discussie in Nederland en België aangaande de invulling van beroepsprofielen en beroepskwalificaties van zorgprofessionals. Mede vanuit besparingsoogpunt, maar ook vanwege werkdrukproblemen in de zorg wordt de verdeling van (medische) taken en handelingen tussen zorgprofessionals onder de loep genomen. Een deel van de traditionele taken van artsen en specialisten wordt steeds meer ondergebracht bij arts-assistenten of verpleegkundig specialisten. Dat verlicht de werkdruk van artsen en specialisten, want op die manier worden meer routinematige en administratieve taken uitbesteed. Daardoor hebben zij meer tijd en ruimte voor de specialistische uitdagingen in hun werk. Uit de resultaten van dit onderzoek blijkt dat de verdeling van het werk rondom 'Samen beslissen' tussen uroloog en verpleegkundig specialist voor beide functies gunstig uitpakt in termen van werkdruk. De uroloog blijft eindverantwoordelijk voor de medische beslissingen en de uiteindelijke behandeling, maar een deel van de voorbereiding is ondergebracht bij de verpleegkundig specialist, die op zijn beurt een duidelijk afgebakende verantwoordelijkheid heeft in het zorgproces. Daarmee is dit een voorbeeld van een goede verdeling en uitbesteding van medische taken en verantwoordelijkheden (beroepskwalificaties) tussen verschillende medische beroepen met oog voor een goede balans tussen werkeisen en energiebronnen (ter voorkoming van werkdruk), maar ook voor een goede balans tussen verantwoordelijkheden en bevoegdheden.

\section{Praktijkbox}

Wat betekenen de resultaten voor de praktijk?

- Organisaties, ziekenhuizen, specialismen en afdelingen die gezamenlijke besluitvorming willen invoeren om patiëntgerelateerde uitkomsten te verbeteren, doen er op basis van deze studie goed aan om na te gaan of gezamenlijke besluitvorming zinvol is in het behandelproces van de te behandelen aandoening. Als er keuzes gemaakt moeten worden die op inhoud relevant verschillend zijn, is het zinvol om gezamenlijke besluitvorming te overwegen. 
- Bij het implementeren van gezamenlijke besluitvorming is het van belang de consequenties van een dergelijke (andere) manier van werken te doordenken in termen van taken en hoe de verschillende taken te verdelen over functies. De manier waarop taken aan functies worden toegewezen, is van belang voor de werkdrukeffecten daarvan. Een goede afweging van de balans tussen werkeisen en energiebronnen is van belang om te voorkomen dat extra taken tot werkverzwaring en (extra) werkdruk leiden.

- Het is van belang om de consequenties van gezamenlijke besluitvorming voor de organisatie en planning van het werk in ogenschouw te nemen. Als gezamenlijke besluitvorming tot langere consulten leidt, zoals in de situatie van dit onderzoek het geval was, dan is het zinvol daar in de planning van het spreekuur rekening mee te houden.

\section{Literatuur}

Benbassat, J., Pilpel, D., \& Tidhar M. (1998). Patients' preferences for participation in clinical decision making: A review of published surveys. Behavioral Medicine, 24, 81-88.

CBS. (2016). Werknemers in zorg ervaren hoge werkdruk. https://www.cbs.nl/nl-nl/nieuws/ 2016/46/werknemers-in-zorg-ervaren-hoge-werkdruk

Brock, D., \& Wartman, S. (1990). When competent patients make irrational choices. New England Journal of Medicine, 322(22), 1595-1599.

Butcher, L. (2013). Giving the patient a say. No, really. Hospitals \& Health Networks, 87(5), 26-31.

Casalino, L., \& Crosson, F. (2015). Physician satisfaction and physician well-being: Should anyone care? Professions and Professionalism, 5(1). https://doi.org/10.7577/pp.954

Christis, J. (1999). Psychische stress, werkstress en werkdruk. Tijdschrift voor HRM, 2, 57-82.

Conway, T., \& Willcocks, S. (1997). The role of expectations in the perceptions of health care quality: Developing a conceptual model. International Journal of Health Care Quality Assurance, 10(3), 131-140.

Coulter, A. (1997). Partnerships with patients: The pros and cons of shared clinical decision-making. Journal of Health Services Research and Policy, 2(2), 112-121.

Deber, R. (1994). Physicians in health care management: 7. The patient-physician partnership: Changing roles and the desire for information. Canadian Medical Association, 151(2), 171-176.

Demerouti, E., Bakker, A., Nachreiner, F., \& Schaufeli, W. (2001). The job demands-resources model of burnout. Journal of Applied Psychology, 86(3), 499-512.

Edwards, A., \& Elwyn, G. (1999). The potential benefits of decision aids in clinical medicine. Journal of the American Medical Association, 282(8), 779-780.

Elwyn, G., Coulter, A., Laitner, S., Walker, E., Watson, P., \& Thomson, R. (2010). Implementing shared decision making in the NHS. British Medical Journal, 341(7780), 971-972.

Elwyn, G., Joseph-Williams, N., Lloyd, A., Kinnersley, P., Cording, E., Rollnick, S., Edwards, A., Frosch, D., Thomson, R., Tomson, D., Dodd, C., \& Barry, M. (2012). Shared decision making: A model for clinical practice. Journal of General Internal Medicine, 27(10), 1361-1367. 
Elwyn, G., Lloyd, A., Joseph-Williams, N., Cording, E., Thomson, R., Durand, M., \& Edwards, A. (2013). Option grids: Shared decision making made easier. Patient Education and Counseling, 90(2), 207-212.

Emanuel, E., \& Emanuel, L. (1992). Four models of the physician-patient relationship. Journal of the American Medical Association, 267(16), 2221-2226.

Firth-Cozens, J. (2015). Doctor satisfaction and the effects on quality - discussion. Professions and Professionalism, 5(1). https://doi.org/10.7577/pp.1332

Gray, R., Doan, B., \& Church, K. (1990). Empowerment and persons with cancer: Politics in cancer medicine. Journal of Palliative Care, 6(2), 33-45.

Griffin, S., Kinmonth, A., Veltman, M., Gillard, S., Grant, J., \& Stewart, M. (2004). Effect on health-related outcomes of interventions to alter the interaction between patients and practitioners: A systematic review of trials. Annals of Family Medicine, 2, 595-608.

Guadagnoli, E., \& Ward, P. (1998). Patient participation in decision-making. Social Science \& Medicine, 47(3), 329-339.

Hacker, W. (1989). Vollständige vs. unvollständige Arbeitstätigkeiten. In S. Greif, H. Holling, \& N. Nicholson (Red.). Arbeits- und Organisationspsychologie (pp. 463-466), München: Psychologie Verlags Union.

Hagbaghery, M., Salsali, M., \& Ahmadi, F. (2004). The factors facilitating and inhibiting effective clinical decision-making in nursing: a qualitative study. BMC Nursing, 3, 2. https://doi.org/10.1186/1472-6955-3-2

Karasek, R.A. (1979). Job demands, job decision latitude, and mental strain: Implications for job redesign. Administrative Science Quarterly, 24(2), 285-309.

Légaré, F., Adekpedjou, R., Stacey, D., Turcotte, S., Kryworuchko, J., Graham, I.D., Lyddiatt, A., Politi, M.C., Thomson, R., Elwyn, G., \& Donner-Banzhoff, N. (2018). Interventions for increasing the use of shared decision making by healthcare professionals. Cochrane Database of Systematic Reviews, Issue 7, Art. No. CDoo6732. doi:10.1002/14651858.CDoo6732.pub4

Levine, M., Gafni, A., \& Markham, B. (1992). A bedside decision instrument to elicit a patient's preference concerning adjuvant chemotherapy for breast cancer. Annals of Internal Medicine, 117(1), 53-58.

Marrin, K., Wood, F., Firth, J., Kinsey, K., Edwards, A., Brain, K., Newcombe, R., Nye, A., Nye, Pickles, T., Hawthorne, K., \& Elwyn, G. (2014). Option grids to facilitate shared decision making for patients with osteoarthritis of the knee: Protocol for a single site, efficacy trial. BMC Health Services Research, 14, 16o. https://doi.org/10.1186/1472-696314-16o

National Health Service. (2011). NHS Survey: NHS Staff Management and Health Service Quality. Retrieved from https://www.gov.uk/government/publications/nhs-staff-management-and-health-service-quality

O'Connor, A., Rostom, A., Fiset, V., Tetroe, J., Entwistle, V., Llewellyn-Thomas, H., Holmes-Rovner, M., Barry, M., \& Jones, J. (1999). Decision aids for patients facing health treatment or screening decisions: Systematic review. British Medical Journal, 319, 731-724.

Schaufeli, W., \& Taris, T. (2013). Het Job Demands-Resources Model: overzicht en kritische beschouwing. Gedrag \& Organisatie, 26(2), 182-204.

Stacey, D., Légaré, F., Lewis, K., Barry, M.J., Bennett, C.L., Eden, K.B., Holmes-Rovner, M., Llewellyn-Thomas, H., Lyddiatt, A., Thomson, R., \& Trevena, L. (2017). Decision aids for people facing health treatment or screening decisions. The Cochrane Database of Systematic Reviews, Issue 4, Art. No. CDoo1431. doi:10.1002/14651858.CDoo1431.pub5 Stiggelbout, A., Pieterse, A., \& De Haes, J. (2015). Shared decision making: Concepts, evidence, and practice. Patient Education and Counseling, 98(10), 1172-1179. 
Tucker, J., \& Adams, S. (2001). Incorporating patients' assessments of satisfaction and quality: An integrative model of patients' evaluations of their care. Managing Service Quality, 11(4), 272-286.

Ware, J., Davies-Avery, A., \& Stewart, A. (1978). The measurement and meaning of patient satisfaction. Health and Medical Care Services Review, 1(1), 5-15.

Werder, P.R., \& Rothlin, P. (2007). Diagnose Boreout. München: Redline Finanzbuch Verlag.

\section{Shared decision making and workload among Dutch health care professionals}

R. Schouteten \& L. Jansen, Gedrag \& Organisatie, volume 32, November 2019, nr. 4, pp. 279-298.

This study investigates the effect of shared decision making on the work and workload of health care professionals in hospitals. In shared decision making, patients are actively involved in the decision making process. Empirical research shows that shared decision making has positive effects on patient related outcomes, however there are no studies into the effects of this way of decision making for the health care professionals involved.

Building on the Job Demands-Resources model, we studied the mechanisms that can explain the effects of shared decision making on health care professionals when applied in the care processes for patients with prostate cancer. The study collected qualitative data on the care processes from ten patients and the two health care professionals involved.

Next to a confirmation of the positive effects for patients, the results show that the health care professionals positively evaluate shared decision making. Regarding workload, the health care professionals report a healthy balance between job demands and resources. The mechanisms to explain these positive results include the carefulness of the design and implementation of such a new way of working. This means that a well-thought out implementation of a new way of working can support keeping workload within healthy limits, even in a high-workload sector.

Key words: shared decision making, healthcare, employee well-being, patient satisfaction 